\title{
Alterations in vasodilator-stimulated phosphoprotein (VASP) phosphorylation: associations with asthmatic phenotype, airway inflammation and $\beta_{\mathbf{2}}$-agonist use
}

\author{
Annette T Hastie*1, Min Wu리 Gayle C Foster ${ }^{1}$, Gregory A Hawkins ${ }^{1}$, \\ Vikas Batra ${ }^{2}$, Katherine A Rybinski², Rosemary Cirelli², James G Zangrilli ${ }^{2}$ \\ and Stephen P Peters ${ }^{1}$
}

Address: ${ }^{1}$ Department of Internal Medicine, \& Center for Human Genomics, Wake Forest University School of Medicine, Winston-Salem, NC, USA and ${ }^{2}$ Department of Medicine, Thomas Jefferson University, Philadelphia, PA, USA

Email: Annette T Hastie* - ahastie@wfubmc.edu; Min Wu - mwu@wfubmc.edu; Gayle C Foster - gcfoster@wfubmc.edu;

Gregory A Hawkins - ghawkins@wfubmc.edu; Vikas Batra - batra72@yahoo.com; Katherine A Rybinski - kathyrybinski@comcast.net; Rosemary Cirelli - lpcc2002@aol.com; James G Zangrilli - james.zangrilli@jefferson.edu; Stephen P Peters - sppeters@wfubmc.edu

* Corresponding author

Published: 15 February 2006

Respiratory Research 2006, 7:25 doi:10.1 186/1465-9921-7-25

This article is available from: http://respiratory-research.com/content/7///25

(C) 2006 Hastie et al; licensee BioMed Central Ltd.

This is an Open Access article distributed under the terms of the Creative Commons Attribution License (http://creativecommons.org/licenses/by/2.0), which permits unrestricted use, distribution, and reproduction in any medium, provided the original work is properly cited.
Received: 02 November 2005

Accepted: 15 February 2006

\begin{abstract}
Background: Vasodilator-stimulated phosphoprotein (VASP) mediates focal adhesion, actin filament binding and polymerization in a variety of cells, thereby inhibiting cell movement. Phosphorylation of VASP via CAMP and cGMP dependent protein kinases releases this "brake" on cell motility. Thus, phosphorylation of VASP may be necessary for epithelial cell repair of damage from allergen-induced inflammation. Two hypotheses were examined: (I) injury from segmental allergen challenge increases VASP phosphorylation in airway epithelium in asthmatic but not nonasthmatic normal subjects, (2) regular in vivo $\beta_{2}$-agonist use increases VASP phosphorylation in asthmatic epithelium, altering cell adhesion.

Methods: Bronchial epithelium was obtained from asthmatic and non-asthmatic normal subjects before and after segmental allergen challenge, and after regularly inhaled albuterol, in three separate protocols. VASP phosphorylation was examined in Western blots of epithelial samples. DNA was obtained for $\beta_{2}$-adrenergic receptor haplotype determination.

Results: Although VASP phosphorylation increased, it was not significantly greater after allergen challenge in asthmatics or normals. However, VASP phosphorylation in epithelium of nonasthmatic normal subjects was double that observed in asthmatic subjects, both at baseline and after challenge. Regularly inhaled albuterol significantly increased VASP phosphorylation in asthmatic subjects in both unchallenged and antigen challenged lung segment epithelium. There was also a significant increase in epithelial cells in the bronchoalveolar lavage of the unchallenged lung segment after regular inhalation of albuterol but not of placebo. The haplotypes of the $\beta_{2^{-}}$ adrenergic receptor did not appear to associate with increased or decreased phosphorylation of VASP.

Conclusion: Decreased VASP phosphorylation was observed in epithelial cells of asthmatics compared to nonasthmatic normals, despite response to $\beta$-agonist. The decreased phosphorylation does not appear to be associated with a particular $\beta_{2}$-adrenergic receptor haplotype. The observed decrease in VASP phosphorylation suggests greater inhibition of actin reorganization which is necessary for altering attachment and migration required during epithelial repair.
\end{abstract}




\section{Background}

Attachment and migration of airway epithelial cells is an important aspect of repair of injury induced by allergens and other agents in asthma. Cytoskeletal reorganization, mediated through actin filament remodeling, is required to facilitate attachment and migration of epithelial cells into damaged areas. The vasodilator-stimulated phosphoprotein (VASP) binds to profilin, F- and G-actin, and mediates actin assembly, bundling and attachment at focal adhesions [1,2]. VASP and two other members of the ENA/VASP family in mammalian cells, MENA (mammalian ENAbled) and EVL (ENA/VASP-like) slow or inhibit fibroblast motility by altering the dynamics of actin filament structure $[3,4]$. However, MENA and EVL, despite shared molecular similarities and normal expression, did not substitute for VASP and reverse compromised cell motility in a wound healing assay of VASP-/- fibroblasts [5].

VASP phosphorylation occurs on two serine and one threonine (Ser 157, Ser 239 and Thr 278) through cAMP and cGMP dependent protein kinases A and G [6-9], and as recently observed in smooth muscle cells, protein kinase C [10]. Phosphorylation by cAMP protein kinase preferentially occurs at Ser 157, whereas phosphorylation by cGMP protein kinase preferentially occurs at Ser 239, both kinases secondarily acting on Thr 278 [7]. The Ser 157 phosphorylation results in decreased migration of the VASP molecule from $46 \mathrm{KD}$ to $50 \mathrm{KD}$ in SDS-gel electrophoresis [6-9]. Functionally, phosphorylation of VASP regulates its interaction with actin, and correlates with detachment and spreading of fibroblasts and epithelial cells $[3,4,9,11,12]$. Thus, the ratio of the $50 \mathrm{KD}$ to the 46 KD molecular form of VASP within a cell sample provides a measure of VASP phosphorylation and indicates active remodeling of the actin cytoskeleton during cell attachment and migration.

We postulated that repair of injury to the airway epithelium during antigen-induced inflammation would involve enhanced phosphorylation of VASP in order to mediate actin cytoskeleton remodeling and cell migration into damaged areas. We further hypothesized that inhalation of the $\beta$-agonist albuterol, would also increase phosphorylation of VASP by stimulation of cAMP-dependent protein kinase activity, and result in altered epithelial cell attachment and mobility. These hypotheses were tested in three protocols using brush samples of airway epithelium obtained from allergic asthmatics and control subjects.

\section{Methods \\ Subjects and bronchoscopic protocols}

Thirty-one individuals characterized as mild allergic (to ragweed) asthmatics based on American Thoracic Society criteria, and 17 nonasthmatic, normal healthy subjects volunteered for the studies approved by the Wake Forest University School of Medicine or the Jefferson Medical College Institutional Review Boards. All volunteers gave informed, written consent to screening, bronchoscopic procedures and characterization as previously described $[13,14]$. Asthmatics had mild intermittent asthma and 29 of the 31 were using only inhaled $\beta_{2}$-agonist on an as needed basis; the remaining 2 asthmatics were using chronic inhaled steroid and long-acting $\beta_{2}$-agonist therapy. These latter two subjects contributed bronchial epithelial cells only to "c" protocol (see below) and DNA for $\beta$-adrenergic receptor haplotyping. Characterization of all subjects included collection of demographic information, standard spirometry, airway reactivity to methacholine, skin reactivity to ragweed allergen (short ragweed antigen, Greer Laboratories, Lenoir, NC) as previously described $[14]$, and $\beta$-adrenergic receptor haplotyping. Results for other investigations on some of the subjects in these studies have been reported: leukocytes and inflammatory mediators (TGF $\beta 1$, TGF $\beta 2$, IL-4, IL-10, IL-13, sphingosine 1-phosphate, sVCAM) in lavage fluid induced by segmental allergen challenge, TRAIL and its receptors, induction of stress proteins in epithelial cells, epithelial cell proliferation and stimulation of fibrogenesis, and $\beta_{2}$-adrenergic receptor signaling [13-22]. Subject demographic and pulmonary function data are listed in Table 1.

Table I: Subject demographics. Data are presented as mean \pm SEM except for $\mathrm{PC}_{20}$ methacholine which are presented as the geometric means.

\begin{tabular}{llll}
\hline Characteristics & Allergic Asthmatic & Nonasthmatic Normal & P Value \\
\hline Number: & 31 & 17 & \\
Gender: & $17 \mathrm{M} / \mathrm{I} 4 \mathrm{~F}$ & $12 \mathrm{M} / 5 \mathrm{~F}$ & $\mathrm{P}=0.22$ \\
Age $(\mathrm{yr}):($ range) & $29.6 \pm 1.3(20-47)$ & $27.1 \pm 1.3(2 \mathrm{I}-33)$ & $\mathrm{P}=0.005$ \\
Ragweed Skin Tests & Positive & Negative & $\mathrm{P}=0.07$ \\
FEV $(\mathrm{L}):$ & $3.33 \pm 0.2$ & $4.06 \pm 0.2$ & \\
FEV $(\%$ predicted): & $84.8 \pm 6$ & $101.3 \pm 3.7$ & $\mathrm{P}=0.002$ \\
PC $_{\mathbf{2 0}}$ Methacholine $(\mathrm{mg} / \mathrm{ml}):$ & $1.0 \pm 0.8$ & $16 \mathrm{at}>32 \mathrm{mg} / \mathrm{ml}$ \\
Serum IgE $(\mathrm{IU} / \mathrm{ml}):$ & $177 \pm \mathrm{I}$ & $1 \mathrm{at} \mathrm{II} \mathrm{mg/ml} \pm 13$ & \\
\hline
\end{tabular}


Table 2: Recovery from injury bronchoscopy protocol. Samples (lavage and brush biopsies) from four bronchoscopic procedures on each of 9 asthmatic and 7 nonasthmatic normal subjects were obtained from unchallenged and antigen (Ag) challenged lung segments according to the procedure day as indicated. A second Ag challenge on day $\mathbf{2}$ was performed to provide an additional challenged segment for day 9 without compromise from prior sampling.

\begin{tabular}{|c|c|c|c|c|c|}
\hline Procedure Day: & & $\mathbf{I}$ & 2 & 9 & 16 \\
\hline \multicolumn{6}{|l|}{ Lung Segment: } \\
\hline Left Lower & (Unchallenged Seg) & Sample & & & \\
\hline Right Middle & (Challenged Seg I) & Ag Challenge & Sample & & Sample \\
\hline Lingula & (Challenged Seg 2) & & $\mathrm{Ag}$ Challenge & Sample & \\
\hline
\end{tabular}

Bronchoalveolar lavage (BAL) and brush biopsies of bronchial epithelium from asthmatic or control subjects were obtained in three separate protocols: $(a)$ before (designated as day 1 ) and $24 \mathrm{hr}, 1$ week and 2 weeks after segmental allergen challenge (SAC) (days 2, 9 and 16, respectively) in a recovery from injury protocol (Table 2 ) ( $\mathrm{n}=16: 9$ asthmatics, 7 nonasthmatic normals); $(\boldsymbol{b})$ before (day 1) and $24 \mathrm{hr}$ after SAC (day 2) at baseline, repeated sampling before and $24 \mathrm{hr}$ after SAC (days 18 and 19) after a two week period of regular inhaled $\beta_{2}$-agonist (albuterol) or placebo, and final repeat sampling (day 25 ) of initial lung segments after 1 additional week of $\beta_{2^{-}}$ agonist or placebo, withdrawn 12 hours prior to bronchoscopy (Table 3 ) ( $\mathrm{n}=7$ asthmatics on $\beta_{2}$-agonist and a repeat of $\mathrm{n}=4$ asthmatics on placebo); and (c) baseline bronchoscopy on asthmatics $(\mathrm{n}=16)$ and nonasthmatic normals $(\mathrm{n}=10)$. All subjects in protocols "a" and "c" received albuterol just prior to bronchoscopy; those subjects enrolled in "b" protocol received albuterol just prior to bronchoscopy only after the two-week period of regular inhaled $\beta_{2}$-agonist (days 18 and 19). Bronchoscopy with allergen challenge (Ag challenge) was preformed as previously described in detail using $10 \mathrm{ml}$ of a $100 \mathrm{X}$ concentration of the minimum antigen dose giving a positive skin test (wheal $\geq 10 \mathrm{~mm}$ with $0.001 \mathrm{RWAU} / \mathrm{ml}$ ) [23]. For bronchoalveolar lavage, 3 aliquots of $50 \mathrm{mls}$ sterile normal saline (warmed to $37^{\circ} \mathrm{C}$ ) were instilled and removed by gentle suction. Brush biopsies of epithelium were obtained from 2-3 cytology brushings combined and processed as reported in detail and below $[18,19]$.

Cells from BAL fluid were pelleted, resuspended and counted [21]. Aliquots of BAL cells ( $10^{5}$ cells) from the autologous lung segment were added to medium in wells surrounding semiporous membrane culture inserts (0.4 $\mu \mathrm{m}$ pore size, Millicell- $12 \mathrm{~mm}$ HA MCE; Millipore, Bedford, MA) containing the epithelial cell aliquots for coculture. Cytospin preparations of BAL cells were stained, and differential counts for epithelial cells (Alcian Blue, ciliated, or other columnar cells, and their sum = "total" epithelial cell counts) were calculated $\left(\times 10^{4} / \mathrm{ml}\right)$.

\section{Epithelial cell culture and western blot analysis of VASP}

Bronchial epithelial cells were cultured $24 \mathrm{hr}$ at air/fluid interface in Millicell culture inserts either without or with $10^{5} \mathrm{BAL}$ cells added to the well surrounding the insert to maintain contact with soluble inflammatory mediators from leukocytes of the same lung segment [18]. Inserts containing epithelial cells were harvested in RIPA buffer (phosphate buffered saline containing 1\% NP40, 0.5\% sodium deoxycholate, $1 \%$ sodium dodecyl sulfate, with protease inhibitors: $0.1 \mathrm{mg} / \mathrm{ml} \mathrm{PMSF}$, aprotinin and 1 $\mathrm{mM}$ sodium orthovanadate). Cell lysates were frozen until analyzed by SDS-PAGE and Western blotting $[18,19]$. Western blots were developed with monoclonal anti-VASP antibody, recognizing both the $46 \mathrm{kD}$ and 50

Table 3: $\beta_{2}$-agonist or placebo regular inhalation and bronchoscopy protocol. Samples (lavage and brush biopsies) from five bronchoscopic procedures were obtained from the unchallenged and Ag challenged lung segments according to the procedure day indicated. Seven asthmatics enrolled in the drug arm, and 4 of these same subjects re-enrolled in the placebo arm. A baseline sample and a $24 \mathrm{hr}$ post Ag challenge sample were obtained before (days I and 2) and after (days 18 and I9) a two week period of regular albuterol or placebo use. The initial baseline unchallenged and challenged lung segments were resampled following one additional week of regular albuterol or placebo use which were discontinued I $2 \mathrm{hr}$ before the final bronchoscopic procedure on day 25 .

\begin{tabular}{|c|c|c|c|c|c|c|c|c|}
\hline Procedure Day: & & $\mathbf{I}$ & 2 & $3-17$ & 18 & 19 & $20-24$ & 25 \\
\hline \multicolumn{9}{|l|}{ Lung Segment: } \\
\hline Lingula & (Unchallenged) & Sample & & & & & & Sample \\
\hline RML & (Challenged) & Challenge & Sample & & & & & Sample \\
\hline & & & & Albuterol 2 puffs, qid & & & & \\
\hline RLL & (Unchallenged) & & & & Sample & & & \\
\hline \multirow[t]{2}{*}{ LLL } & (Challenged) & & & & Challenge & Sample & & \\
\hline & & & & & & & Albuterol 2 puffs, qid & \\
\hline
\end{tabular}




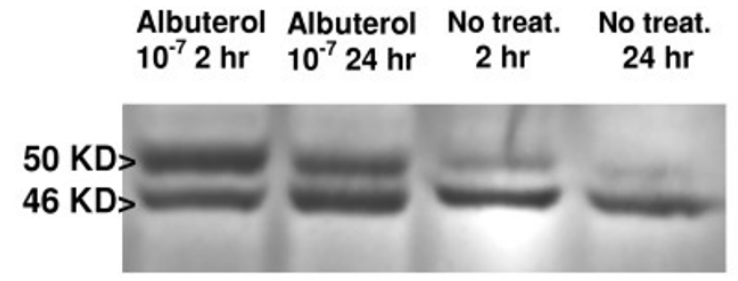

Figure I

Western blot of bronchial epithelial cells demonstrating 50 and 46 KD isoforms of VASP. Representative western blot of bronchial epithelial cells from an asthmatic subject developed with anti-VASP antibody to show the banding pattern for the $46 \mathrm{KD}$ and phosphorylated $50 \mathrm{KD}$ isoforms of VASP. Bronchial epithelial cells received either no treatment for 2 or $24 \mathrm{hr}$ or treatment with $10^{-7}$ albuterol for 2 or $24 \mathrm{hr}$. The treatment with albuterol increased the band density for the 50 KD VASP isoform relative to the $46 \mathrm{KD}$ isoform, greater at $2 \mathrm{hr}$ than after $24 \mathrm{hr}$ chronic albuterol treatment.

kD (phosphorylated at Ser 157) molecular forms (Transduction Laboratories, Lexington, KY) (see Figure 1), and quantitated by densitometry (Kodak 1D Image Analysis System). This previously reported method [18] provides a linear response for band densities of the 50/46 KD VASP over the range of epithelial cell protein concentration examined.

To ascertain that epithelial cells of asthmatics were responsive to $\beta_{2}$-agonists, aliquots of epithelial cells from some asthmatics were stimulated for $2 \mathrm{hr}$ after the initial $24 \mathrm{hr}$ incubation with in vitro addition of albuterol $\left(10^{-7}\right.$ $\mathrm{M})$, salmeterol $\left(10^{-7} \mathrm{M}\right)$ or no stimulus before harvest and handling as described above.

\section{Haplotyping of $\beta_{2}$-adrenergic receptor}

DNA was isolated from cell pellets or lysates, amplified by GenomiPhi DNA kit (Amersham Biosciences, Piscataway, $\mathrm{NJ}$ )[24] if low in yield, and haplotyped for the $\beta$-adrenergic receptor according to the multiplex ARMS PCR assay [25]. DNA of 11 asthmatics and 7 nonasthmatic normals were sequenced by standard methodology [26] for the $\beta$ adrenergic receptor in addition to haplotyping to confirm haplotype assignment at the 13 SNP sites defined by Drysdale et al. [27].

\section{Statistical analysis}

Data were tested for normal distribution and equal variances by Sigmastat (version 2.0) and examined by one- or two-way repeated measures analysis of variance, post hoc pairwise comparisons by Tukey test at individual points,

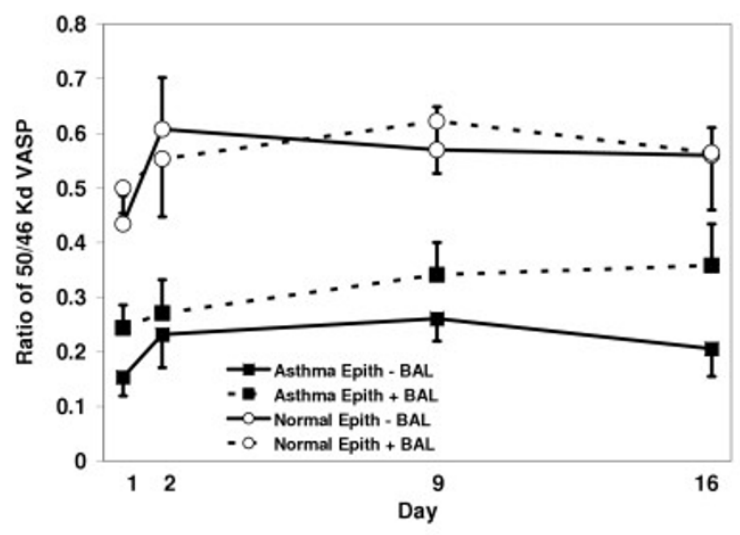

Figure 2

VASP phosphorylation in epithelial cells of asthmatic and normal control subjects following allergen challenge. Ratio of 50/46 KD VASP in epithelial cells of asthmatic (squares) and nonasthmatic normal subjects (circles) from before (Day I) and after segmental allergen challenge (Days 2, 9 and 16). Epithelial cells were cultured for $24 \mathrm{hr}$ with (dashed lines) or without (solid lines) BAL cell co-culture. Segmental allergen challenge increased the phosphorylation of VASP in asthmatic and normal epithelial cells but did not reach significance $(p=0.08)$. BAL cell co-culture exerted a significant effect on VASP phosphorylation in asthmatic $(p=0.022)$ but not normal epithelial cells. Nevertheless, asthmatic epithelial cells had significantly less VASP phosphorylation (lower 50/46 KD VASP ratio) at all timepoints compared to nonasthmatic normal epithelial cells $(p<$ 0.00 I without BAL cells; $p=0.006$ with BAL cells).

paired or unpaired t test, as appropriate. A $\mathrm{p}<0.05$ was considered significant, and a $0.05<\mathrm{p}<0.1$, a trend.

\section{Results \\ Allergen-induced inflammation effect on VASP phosphorylation}

To test the hypothesis that allergen-induced inflammation would increase phosphorylation of VASP, we examined the ratio of phosphorylated $50 \mathrm{KD}$ to $46 \mathrm{KD}$ VASP in epithelium from allergic asthmatic and nonallergic nonasthmatic normal subjects before and after segmental allergen challenge in the recovery from injury protocol (Table 2). The ratio of 50/46 KD VASP in epithelial cells of both asthmatic and normal subjects increased after Ag challenge ( $p=0.08$ for the effect of day on 50/46 KD VASP ratio), but did not reach significance in either group (Figure 2). Co-culture of epithelial cells with autologous BAL cells within the asthmatic subjects did significantly elevate the 50/46 KD VASP ratio ( $\mathrm{p}=0.022)$, but not within nonasthmatic normal subjects. The total VASP expression (46 $\mathrm{KD}+50 \mathrm{KD}$ relative to an internal $76 \mathrm{KD}$ protein [18]) 

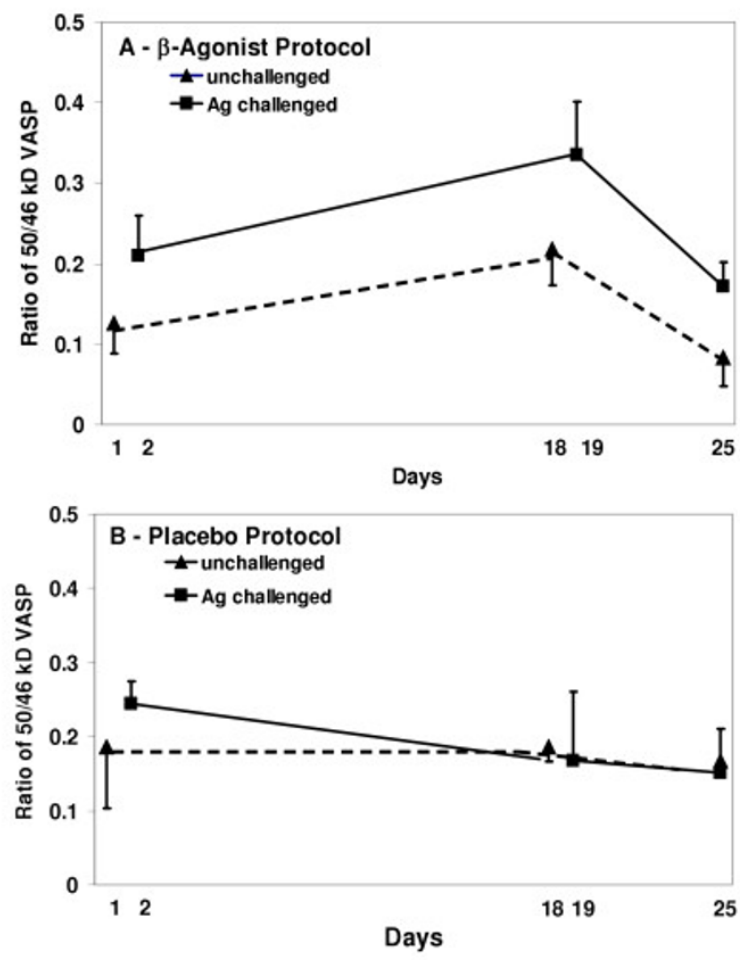

Figure 3

VASP phosphorylation in epithelial cells of asthmatics after regular albuterol or placebo inhalation. Ratio of 50/46 KD VASP in asthmatic epithelial cells without BAL cell co-culture from subjects either on regular albuterol inhalation (A) or on regular placebo inhalation (B). Epithelial cells were obtained from unchallenged lung segments (Days I, and I8, broken lines), from Ag challenged lung segments (Days 2, and 19, solid lines) and from resampled lung segments on Day 25 (unchallenged Day I segment, and challenged Day 2 segment). Two weeks of regular $\beta_{2}$-agonist inhalation, but not placebo inhalation, resulted in significantly increased phosphorylation of VASP in both unchallenged and challenged lung segments' epithelium $(p=0.009)$. Overall, VASP phosphorylation, i.e. a larger 50/46 KD VASP ratio, was greater in epithelium from challenged than from unchallenged lung segments in the regular $\beta_{2}$-agonist inhalation protocol ( $P$ $=0.017)$, but not in the placebo inhalation protocol ( $\mathrm{B}$ panel).

was also examined, but did not significantly differ between asthmatics' and normals' epithelial cells ( $\mathrm{p}=$ $0.55)$, over the 4 timepoints $(\mathrm{p}=0.87)$, or with BAL cell co-culture ( $p=0.97$ ) (data not shown). Asthmatic epithelial cells however, had a significantly lower ratio of 50/46 $\mathrm{kD}$ VASP compared to normal epithelial cells at baseline and throughout the two weeks post-challenge, both without BAL cell co-culture $(\mathrm{p}<0.001)$ and with BAL cell coculture $(\mathrm{p}=0.006)$.
Regular inhaled $\beta_{2}$-agonist effect on VASP phosphorylation To test the hypothesis that regular inhalation of $\beta_{2}$-agonist in asthmatics would increase VASP phosphorylation, we examined the ratio of $50 \mathrm{KD}$ to $46 \mathrm{KD}$ VASP before and after two weeks regular in vivo use of albuterol or placebo, and after an additional one week of regular use terminating $12 \mathrm{hr}$ before the final bronchoscopy (Table 3). After two weeks inhaled regular $\beta_{2}$-agonist use, the 50/46 KD VASP ratio was increased at day 18-19 for both unchallenged and Ag challenged segments' epithelium (effect for day, $\mathrm{p}=0.009$; day $18-19$ versus day $1-2, \mathrm{p}=0.07$; day $18-19$ versus day $25, \mathrm{p}=0.008$ ), but not after placebo ( $\mathrm{p}$ $=0.79$ ) in epithelial cells without BAL cell co-culture (Figure 3). The VASP ratio overall was greater in the Ag challenged lung segment versus the unchallenged lung segment $(\mathrm{p}=0.017)$ in the $\beta$-agonist protocol (Figure $3 \mathrm{~A})$, but there was no statistical interaction for the effect of day with the lung segment, either challenged or unchallenged.

To confirm that the epithelial cells from asthmatics responded to both short and long-acting $\beta_{2}$-agonists, aliquots of epithelium from four asthmatics at baseline were stimulated in vitro with either $10^{-7} \mathrm{M}$ albuterol, $10^{-7} \mathrm{M}$ salmeterol or unstimulated for $2 \mathrm{hr}$, and analyzed for 50/46 KD VASP. The VASP ratio in epithelial cells of all asthmatics was significantly increased by albuterol compared to unstimulated, but not by salmeterol $(50 \mathrm{KD} / 46 \mathrm{KD}$ VASP: $10^{-7} \mathrm{M}$ albuterol $=0.267 \pm 0.06 ; 10^{-7} \mathrm{M}$ salmeterol $=0.36$ \pm 0.14 , unstimulated $=0.11 \pm 0.04 ; \mathrm{p}=0.018$ for albuterol vs unstimulated, $\mathrm{p}=0.13$ for salmeterol vs unstimulated).

To determine whether the significant increase in VASP phosphorylation resulted in altered epithelial cell attachment, the numbers of epithelial cells in bronchoalveolar lavage fluid were quantitated and compared between regular albuterol use and placebo. Cells in lavage fluid from unchallenged lung segments were examined to avoid epithelial shedding due to the allergen-induced inflammation in challenged segments. Day 18 BAL leukocyte differential counts did not change from baseline, indicating no spillover of inflammatory response into the unchallenged lung segment $(\mathrm{p}=0.44$ for eosinophils, $\mathrm{p}=$ 0.56 for neutrophils, $\mathrm{p}=0.28$ for lymphocytes). Significantly increased numbers of Alcian blue-stained, mucin containing epithelial cells were observed in the lavage fluid of unchallenged segments of asthmatics after 2 weeks of $\beta_{2}$-agonist, but not placebo ( $p<0.001$ for group, $\mathrm{p}=0.014$ for day and $\mathrm{p}=0.004$ for group $\times$ day interaction) (Figure 4). The number of mucin-containing cells correlated with the 50/46 KD VASP ratio observed ( $\mathrm{R}=$ $0.577, \mathrm{p}=0.049$ ). Concomitantly, significantly increased total epithelial cell numbers in lavage fluid were observed for $\beta_{2}$-agonist but not placebo ( $\mathrm{p}<0.001$ for group, and $\mathrm{p}$ $=0.014$ for group $\times$ day interaction $)$. 

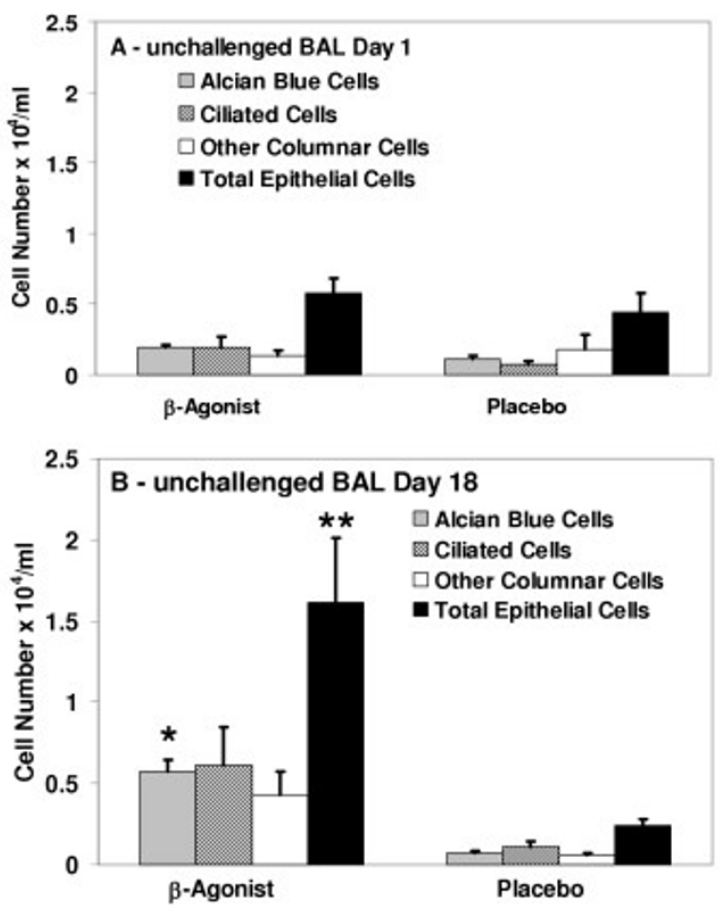

Figure 4

Numbers of epithelial cells in control segment BAL fluid from asthmatics before and after regular $\beta$-agonist or placebo inhalation. Epithelial cell numbers in unchallenged lung segment $B A L$ fluid prior to any inhalation (A, day $I$ ) and in unchallenged lung segment BAL fluid after two weeks regular inhalation of albuterol or placebo ( $B$, day 18). The numbers of cells stained with Alcian Blue for mucous (gray shaded bars), nonspecific esterase for ciliated (hatched bars), other columnar cells (open bars) and the total of these three (solid bars) per $\mathrm{ml}$ were increased after two weeks of regularly inhaled albuterol compared to placebo ( $p<0.00$ I for both Alcian blue and total groups). There was also a significant effect for day in Alcian blue stained cells (day I versus day I8, $p=0.014$ ) and a significant group $\times$ day interaction in Alcian blue and total cell groups for albuterol inhalation $(p=0.004$ and $p=0.014$, respectively).

\section{$\beta_{2}$-adrenergic receptor haplotype and VASP} phosphorylation

Different haplotypes of the $\beta_{2}$-adrenergic receptor are reported to alter receptor expression and in vivo responsiveness [27]. Thus, we determined $\beta_{2}$-adrenergic receptor haplotypes of the asthmatic and nonasthmatic normal subjects, to examine whether the differences in baseline epithelial VASP phosphorylation between asthmatic and normal subjects might be due to increased representation of a particular $\beta_{2}$-adrenergic receptor haplotype. Additional asthmatic and normal subjects, for whom both haplotype and 50/46 KD VASP data were available, were added to above subjects (Table 4). The overall 50/46 KD
VASP ratio (mean \pm sem) was significantly increased in nonasthmatic normal versus asthmatic subjects $(0.38 \pm$ 0.02 versus $0.16 \pm 0.01$, respectively; $\mathrm{p}<0.001$, two-tailed $t$ test) as observed above (Figure 2). Asthmatic subjects tended to have several less frequent $\beta_{2}$-adrenergic receptor haplotypes (for example: 1, 9, 10, and 12) than normals, and more often had the 4/4 homozygous haplotype, which has arginine at amino acid 16 [25,27]. The $4 / 4$ haplotype is reported to be less responsive to $\beta_{2}$-agonist [27]. Nevertheless, these haplotypes did not appear to substantially effect the 50/46 KD VASP ratio. A comparison of the more frequent 2/4 heterozygous haplotype for the 50/46 KD VASP ratio still remained different: $0.41 \pm 0.07$ nonasthmatic normals versus $0.16 \pm 0.04$ asthmatic subjects ( $\mathrm{p}$ $=0.002$, two-tailed $t$ test).

\section{Discussion}

Recent investigations into asthma pathogenesis have begun to focus, not on the acute inflammatory events involved with asthmatic airway inflammation, but on aberrant repair mechanisms which appear to be present [28-30]. This work focused on vasodilator-stimulated phosphoprotein (VASP) which is predicted to be involved in epithelial repair mechanisms by mediating focal adhesion, actin filament binding and polymerization, and ultimately, epithelial cell mobility. Reports published during the course of our studies have shown that detachment of kidney epithelial cells increases protein kinase A activity and its phosphorylation of VASP [12], as well as a transient increase in VASP expression [31]. Although there was some increase in total VASP ( $46 \mathrm{KD}+50 \mathrm{KD}$ forms) in asthmatics compared to normals on day 2 in the recovery from injury protocol, the difference was not significant, and probably does not contribute substantially to cell adherence and motility. We hypothesized that asthmatics would demonstrate increased VASP phosphorylation compared to nonasthmatic, normal subjects to permit actin remodeling and cell migration for repair of inflammatory injury. Instead, we observed a potential defect as shown by decreased VASP phosphorylation in asthmatic epithelial cells prior to and following allergeninduced injury compared to normal subjects. Increased VASP phosphorylation in response to segmental antigen challenge was modest in both asthmatic and nonasthmatic normal epithelial cells, but overall a profound decrease in the VASP phosphorylation was observed in asthmatic epithelial cells at all time points examined. The reduced VASP phosphorylation in epithelial cells of asthmatics was confirmed by expanded examination of an additional group of subjects, both asthmatic and normal (Table 4). It has been previously shown that blocking of phosphorylation at MENA Ser 236, which corresponds in molecular structure to VASP Ser 157, or depletion of ENA/ VASP results in increased cell spreading and reduced functional control of cell motility in a number of model sys- 
Table 4: Mean of 50 KD/46 KD VASP ratio in epithelial cells according to $\beta_{2}$-adrenergic receptor haplotype. Specific $\beta_{2}$-adrenergic receptor haplotypes are shown with the mean ratio of 50/46 KD VASP for nonasthmatic normals or asthmatics having that haplotype. Asthmatics tended to have haplotype 4 which contains Arg at amino acid 16, and rarer haplotypes such as I, 9, and I0 than nonasthmatic normals. The overall reduced phosphorylation of VASP (higher 50/46 KD ratio) in asthmatics compared to normals does not appear associated with a specific haplotype.

\begin{tabular}{|c|c|c|c|c|c|c|c|c|c|c|c|}
\hline Haplotype & $2 / 2$ & $2 / 4$ & $2 / 6$ & $4 / 4$ & $4 / 6$ & $6 / 10$ & $1 / 1$ & $4 /(1,9,12)^{*}$ & $4 / 10$ & $1 / 10$ & $6 / 9$ \\
\hline \multicolumn{12}{|l|}{ Normal: } \\
\hline Total $\mathbf{N}=17$ & $N=6$ & $N=5$ & $N=3$ & $N=1$ & & & & $N=1$ & $N=1$ & & \\
\hline $\begin{array}{l}\text { Mean 50/46 KD } \\
\pm \text { SEM }\end{array}$ & $\begin{array}{l}.307 \\
\pm 0.07\end{array}$ & $\begin{array}{l}.408 \\
\pm 0.07\end{array}$ & $\begin{array}{l}.455 \\
\pm 0.10\end{array}$ & .475 & & & & .168 & .491 & & \\
\hline \multicolumn{12}{|l|}{ AsthmaTic: } \\
\hline Total $\mathbf{N}=\mathbf{3 0}$ & $N=2$ & $N=9$ & & $N=8$ & $N=3$ & $N=1$ & $N=2$ & $N=3$ & & $N=1$ & $N=1$ \\
\hline Mean 50/46 KD & .230 & $.163 \dagger$ & & .164 & .147 & .187 & .233 & .110 & & .094 & .046 \\
\hline \pm SEM & \pm 0.01 & \pm 0.04 & & \pm 0.03 & \pm 0.07 & & \pm 0.00 & \pm 0.02 & & & \\
\hline
\end{tabular}

*The haplotyping method could not distinguish among these infrequent haplotypes $(1,9$, and 12 )

†Asthmatics versus Normals, $\mathrm{p}=0.002$ (two-tailed $t$ test, equal variance)

tems [3-5,11]. More directly, $10 \mu \mathrm{M} \mathrm{PGE}_{1}$ converts $60 \%$ of the $46 \mathrm{KD}$ VASP to $50 \mathrm{KD}$ VASP and completely inhibits platelet aggregation as a measure of cell-cell adhesion [6]. Thus, even partial conversion of VASP to its phosphorylated form has significant impact. This suggests one potential mechanism for aberrant epithelial repair in asthmatics: defective or diminished VASP phosphorylation may indicate abnormal epithelial motility. Confirming defective epithelial cell motility in asthmatics in vivo will be challenging, but is a necessary next step in this work.

While segmental antigen challenge did not significantly increase VASP phosphorylation in the recovery from injury protocol "a", there was a trend toward a significant increase, which was confirmed in asthmatics enrolled in the regular $\beta$-agonist inhalation protocol " $\mathrm{b}$ ". In addition, leukocytes in bronchoalveolar lavage fluid from asthmatics co-cultured with autologous epithelium did significantly increase VASP phosphorylation, unlike the leukocytes from nonasthmatic normal subjects, suggesting a soluble signal from the BAL leukocytes to epithelial cells in asthmatics. What the signal(s) may be remains to be determined, but other work from our laboratory suggests certain growth factors such as TGF $\beta$, could be involved.

Because VASP becomes phosphorylated by cAMP-dependent protein kinase, we also hypothesized that both in vivo and in vitro exposure of epithelial cells to a $\beta$-agonist, which increases cyclic AMP levels, should increase VASP phosphorylation. As predicted, regularly inhaled albuterol increased VASP phosphorylation in vivo and apparently altered epithelial cell adhesion, producing significantly greater numbers of epithelial cells shed into bronchoalveolar lavage fluid from unchallenged lung segments exposed only to the $\beta$-agonist, without any allergen-induced inflammation. The $\beta$-agonist effect on VASP phosphorylation was short-lived and the ratio of 50/46
KD VASP returned to baseline within $12 \mathrm{hr}$ of the last albuterol inhalation in vivo. Whether the increased epithelial cell detachment induced by albuterol inhalation returns to baseline as quickly has not been determined. $\beta$ agonist use may therefore produce conflicting effects on asthmatic epithelium. $\beta$-agonists inhibit keratinocyte migration by $\beta_{2}$-adrenergic receptor activation of the serine/threonine phosphatase PP2A [32], the principal phosphatase which dephosphorylates VASP [33], and at the same time activate cAMP-dependent protein kinase phosphorylation of VASP [6-9]. Thus, $\beta$-agonists may promote epithelial repair by enhancing both phosphorylation and dephosphorylation of VASP in actin filament restructuring, but may also promote epithelial damage by increasing the detachment of epithelial cells from the airway. These results also caution against considering as "baseline" or "control," samples obtained from asthmatics receiving $\beta$-agonist therapy without an appropriate washout interval.

Genetic variation and altered function of the $\beta 2$-adrenergic receptor could potentially contribute to the differences in VASP phosphorylation observed between asthmatics and nonasthmatic normal subjects [27]. However, examination of 50/46 KD VASP ratio grouped according to $\beta 2$ adrenergic receptor haplotype for our study subjects did not reveal any specific haplotype bias, either homozygous or heterozygous, affecting VASP phosphorylation. Although the numbers of subjects in any one haplotype classification were limited, the largest 2/4 haplotype group, nonasthmatic normal subjects showed a significantly increased ratio compared to asthmatic subjects. It is possible that other characteristics of the $\beta 2$-adrenergic receptor gene (for example, stability of message due to variation in the 3' untranslated region, [34]), variation in other components in the signaling cascade such as cAMP dependent protein kinase A [6-9], or activation of protein kinase C [10], genetic variation in VASP itself, or differ- 
ences in the activity of protein phosphatases [33] between asthmatics and normals may contribute to the observed disparity in VASP phosphorylation here between asthmatic and normal subjects. Work is currently addressing these areas of inquiry.

\section{Conclusion}

Phosphorylation of VASP is significantly reduced in bronchial epithelial cells from asthmatics compared to nonasthmatic normal subjects, although inducible by $\beta$-agonist treatment either in vitro or in vivo. The reduced ratio of phosphorylated to unphosphorylated VASP in asthmatics does not appear associated with genetic variation in the $\beta_{2}$-adrenergic receptor. Regular inhalation of $\beta$-agonist results in increased VASP phosphorylation in epithelial cells and increased epithelial cell detachment from the airways.

\section{List of abbreviations}

VASP, vasodilator-stimulated phosphoprotein; ENA, ENAbled; MENA, mammalian ENAbled; EVL, ENA/VASPlike; BAL, bronchoalveolar lavage; SAC, segmental allergen challenge;

\section{Competing interests}

The author(s) declare that they have no competing interests.

\section{Authors' contributions}

ATH conceived the study, supervised data collection, statistical analysis and interpretation, and drafted the manuscript. MW and KAR processed samples from bronchoscopy, and analyzed VASP data from western blots. GCF processed DNA from subjects, determined $\beta$ adrenergic receptor haplotype, and with $\mathrm{GAH}$, sequence of $\beta$-adrenergic receptor; both provided drafting and critical comment on revision of the manuscript. $\mathrm{RC}, \mathrm{VB}$ and JGZ consented and enrolled subjects, performed bronchoscopies, processed samples and critically commented on the manuscript. SPP participated in study design and coordination, analysis, writing and critical revision of the manuscript.

\section{Acknowledgements}

The authors thank their volunteer subjects who made this work possible, the Jefferson Medical College Airways Inflammation Research Group, and the Wake Forest University Cloverdale Research Facility for all their assistance with these studies. Funding for this work was obtained from NIH awards HL67663, HL69167 and Al24509, and Wake Forest University General Clinical Research Center, M0I RR 07I 22.

\section{References}

I. Krause M, Dent EW, Bear JE, Loureiro JJ, Gertler FB: ENA/VASP Proteins: Regulators of the actin cytoskeleton and cell migration. Annu Rev Cell Dev Biol 2003, 19:54I-564.

2. Krause M, Bear JE, Loureiro JJ, Gertler FB: The Ena/VASP enigma. J Cell Sci 2002, I I 5:472 I-4726.
3. Bear JE, Loureiro JJ, Livoba I, Fassler R, Wehland J, Gertler FB: Negative regulation of fibroblast motility by Ena/VASP proteins. Cell 2000, 101:717-728.

4. Bear JE, Svitkina TM, Drause M, Schafer DA, Loureiro J], Strasser GA, Maly IV, Chaga OY, Cooper JA, Borisy GG, Gertler FB: Antagonism between Ena/VASP proteins and actin filament capping regulates fibroblast motility. Cell 2002, 109:509-52I.

5. Arguinzonis MIG, Galler AB, Walter U, Reinhard M, Simm A: Increased spreading, rac/p2 I-activated kinase (PAK) activity, and compromised cell motility in cells deficient in vasodilator-stimulated phosphoprotein (VASP). J Biol Chem 2002, 277:45604-456I0.

6. Halbrugge M, Friedrich $C$, Eigenthaler M, Schanzenbacher P, Walter $\mathrm{U}:$ Stoichiometric and reversible phosphorylation of a $46 \mathrm{kDa}$ protein in human platelets in response to CGMP- and CAMPelevating vasodilators. J Biol Chem 1990, 265:3088-3093.

7. Butt E, Abel K, Krieger M, Palm D, Hoppe V, Hoppe J, Walter U: CAMP- and CGMP-dependent protein kinase phosphorylation sites of the focal adhesion vasodilator-stimulated phosphoprotein (VASP) in vitro and in intact human platelets. J Biol Chem 1994, 269:14509-145I7.

8. Smolenski A, Bachmann C, Reinhard K, Honig-Liedl P, Jarchau T, Hoschuetzky $\mathrm{H}$, Walter $\mathrm{U}$ : Analysis and regulation of vasodilatorstimulated phosphoprotein serine 239 phosphorylation in vitro and in intact cells using a phosphospecific monoclonal antibody. J Biol Chem 1998, 273:20029-20035.

9. Harbeck B, Huttelmaier S, Schluter K, Jockusch BM, Illenberger S: Phosphorylation of the vasodilator-stimulated phosphoprotein regulates its interaction with actin. J Biol Chem 2000, 275:308i7-30825.

10. Chitaley K, Chen L, Galler A, Walter U, Daum G, Clowes AW: Vasodilator-stimulated phosphoprotein is a substrate for protein kinase C. FEBS Letters 2004, 556:21I-215.

II. Loureiro J], Rubinson DA, Bear JE, Baltus GA, Kwiatkowski AV, Gertler FB: Critical roles of phosphorylation and actin binding motifs, but not the central proline-rich region for Enal Vasodilator-stimulated phosphoprotein (VASP) function during cell migration. Mol Biol Cell 2002, 13:2533-2546.

12. Howe AK, Hogan BP, Juliano RL: Regulation of vasodilator-stimulated phosphoprotein phosphorylation and interaction with Abl by protein kinase A and cell adhesion. J Biol Chem 2002, 277:38|2|-38|26.

13. Hastie AT, Kraft WK, Nyce KB, Zangrilli JG, Musani AI, Fish JE, Peters SP: Asthmatic epithelial cell proliferation and stimulation of collagen production. Human asthmatic epithelial cells stimulate collagen type III production by human lung myofibroblasts after segmental allergen challenge. Am J Respir Crit Care Med 2002, 165:266-272.

14. Shaver JR, Zangrilli J, Cho S-K, Cirelli RA, Pollice MB, Hastie AT, Fish $J E$, Peters SP: Kinetics of development and recovery of the lung from IgE-mediated inflammation: dissociation of pulmonary eosinophilia, lung injury, and eosinophil-active cytokines. Am J Respir Crit Care Med 1997, I 55:442-448.

15. Ammit AJ, Hastie AT, Edsall LC, Hoffman RK, Amrani Y, Krymskaya VP, Kane SA, Peters SP, Penn RB, Spiegel S, Panettieri RA: Sphingosine I-phosphate modulates human airway smooth muscle cell functions that promote inflammation and airway remodeling in asthma. FASEB J 200I, 15:1212-1214.

16. Batra V, Musani Al, Hastie AT, Khurana S, Carpenter KA, Zangrilli JG, Peters SP: Bronchoalveolar lavage fluid concentrations of transforming growth factor (TGF)- $\beta$ I, TGF- $\beta 2$, interleukin (IL)-4 and IL- I 3 after segmental allergen challenge and their effects on $\alpha$-smooth muscle actin and collagen III synthesis by primary human lung fibroblasts. Clin Exp Allergy 2004, 34:437-444.

17. Colavita AM, Hastie AT, Musani Al, Pascual RM, Reinach AJ, Lustine HT, Galati SA, Zangrilli JG, Fish JE, Peters SP: Kinetics of IL- I 0 production after segmental antigen challenge of atopic asthmatic subjects. J Allergy Clin Immunol 2000, I06:880-886.

18. Hastie AT, Everts KB, Shaver JR, Cirelli R, Zangrilli JG, Pollice MB, Fish JE, Peters SP: $\beta_{2}$-Agonist-elevated stress response in human bronchial epithelial cells in vivo and in vitro. Lung 1997, 175:287-298.

19. Hastie AT, Everts KB, Zangrilli JG, Shaver JR, Pollice MB, Fish JE, Peters SP: HSP27 elevated in mild allergic inflammation pro- 
tects airway epithelium from $\mathrm{H}_{2} \mathrm{SO}_{4}$ effects. Am J Physiol (Lung Cell Mol Physiol 17) 1997, 273:L40I-409.

20. Penn RB, Shaver JR, Zangrilli JG, Pollice M, Fish JE, Peters SP, Benovic $\mathrm{J} L$ : Effects of inflammation and acute beta-agonist inhalation on beta 2-AR signaling in human airways. Am J Physiol 1996, 27 I:L60I-608.

21. Robertson NM, Zangrilli JG, Steplewski A, Hastie AT, Lindemeyer RG, Planeta MK, Smith MK, Innocent N, Musani Al, Pascual R, Peters S, Litwack G: Differential expression of TNF-related apoptosis-inducing ligand (TRAIL) and TRAIL receptors in allergic asthmatics following segmental antigen challenge: Evidence for a role of TRAIL in eosinophil survival. I Immunol 2002, 169:5986-5996.

22. Zangrilli JG, Shaver JR, Cirelli RA, Cho S-K, Garlisi CG, Falcone A, Cuss FM, Fish JE, Peters SP: sVCAM-I levels after segmental antigen challenge correlate with eosinophil influx, IL-4 and IL-5 production, and the late phase response. Am J Respir Crit Care Med 1995, I5 I: |346-| 453.

23. Shaver JR, O'Connor JJ, Pollice M, Cho S-K, Kane GC, Fish JE, Peters SP: Pulmonary inflammation after segmental ragweed challenge in allergic asthmatics and nonasthmatics. Am J Respir Crit Care Med 1995, 152: I I89-1 197.

24. Dean FB, Hosono S, Fang L, Wu X, Faruqi AF, Bray-Ward P, Sun Z, Zong Q, Du Y, Du J, Driscoll M, Song W, Kingsmore SF, Egholm M, Lasken RS: Comprehensive human genome amplification using multiple displacement amplification. Proc Natl Acad Sci USA 2002, 99:526I-5266.

25. Littlejohn MD, Taylor DR, Miller AL, Kennedy MA: Determination of $\beta 2$-adrenergic receptor (ADRB2) haplotypes by a multiplexed polymerase chain reaction assay. Hum Mutat 2002, 20:479-487.

26. Hawkins GA, Amelung PJ, Smith RS, Jongepier H, Howard TD, Koppelman GH, Meyers DA, Bleecker ER, Postma DS: Identification of polymorphisms in the human glucocorticoid receptor gene (NR3CI) in a multi-racial asthma case and control screening panel. DNA Seq 2004, 15:167-173.

27. Drysdale CM, McGraw DW, Stack CB, Stephens JC, Judson RS, Nandabalan K, Arnold K, Ruano G, Liggett SB: Complex promoter and coding region $\beta 2$-adrenergic receptor haplotypes alter receptor expression and predict in vivo responsiveness. Proc Natl Acad Sci USA 2000, 97: 10483-10488.

28. Davies DE, Holgate ST: Asthma: the importance of epithelial mesenchymal communication in pathogenesis. Inflammation and the airway epithelium in asthma. Int J Biochem Cell Biol 2002, 34:1520-6.

29. Cohn L, Elias JA, Chupp GL: Asthma: mechanisms of disease persistence and progression. Annu Rev Immunol 2004, 22:789-8I5.

30. Holtzman MJ, Morton JD, Shornick LP, Tyner JW, O'Sullivan MP, Ant $A$, Lo $M$, Castro $M$, Walter MJ: Immunity, inflammation, and remodeling in the airway epithelial barrier: epithelial-viralallergic paradigm. Physiol Rev 2002, 82:19-46.

31. Quinlan MP: Vinculin, VASP, and profilin are coordinately regulated during actin remodeling in epithelial cells, which requires de novo protein synthesis and protein kinase signal transduction pathways. I Cell Physiol 2004, 200:277-290.

32. Pullar CE, Chen J, Isseroff RR: PP2A activation by $\beta_{2}$-adrenergic receptor agonists. J Biol Chem 2003, 278:22555-22562.

33. Abel K, Mieskes G, Walter U: Dephosphorylation of the focal adhesion protein VASP in vitro and in intact human platelets. FEBS Letters 1995, 370: 184-188.

34. Tholanikunnel BG, Malbon CC: A 20-nucleotide (A+U)-rich element of $\beta_{2}$-adrenergic receptor $\left(\beta_{2} A R\right)$ mRNA mediates binding to $\beta_{2} A R$-binding protein and is obligate for agonistinduced destabilization of receptor mRNA. J Biol Chem 1997, 272: I|47|-I| 478 .

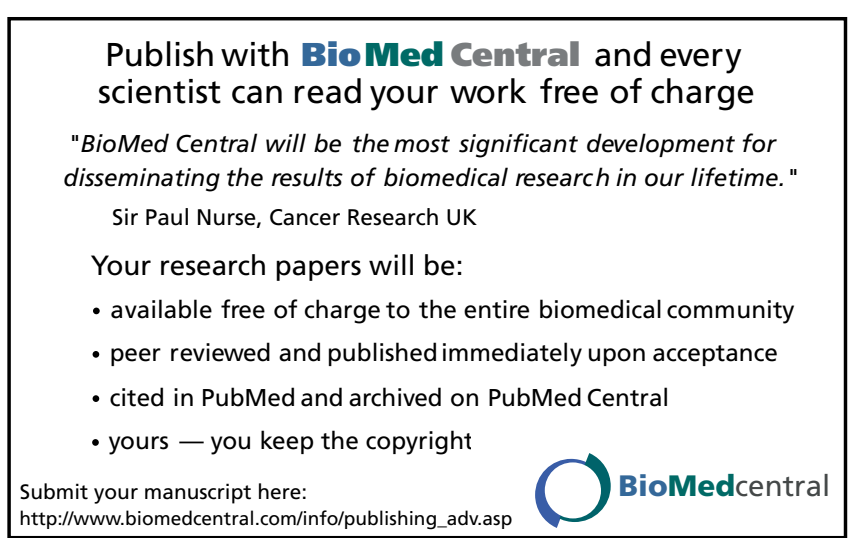

